Images in...

\title{
MR spectroscopy in tuberculoma of brain
}

\author{
Manish Gutch, Nirdesh Jain, Avinash Agrawal, Aniyang Modi
}

Department of Internal Medicine, CSM Medical University, Lucknow, Uttar Pradesh, India

Correspondence to Dr Avinash Agrawal, icuexpert@gmail.com

\section{DESCRIPTION}

A 26 year-old-man developed progressive weakness of all limbs, hoarseness of voice and dysphagia over a period of 10 days. The patient was conscious, oriented and vital parameters were within normal limits. Neurological examination revealed; horizontal and torsional nystagmus, bilateral 9 th and 10th cranial nerve involved, 3/5 muscle power in all limbs and sensory system was intact. MRI brain showed multiple small conglomerated ring enhancing lesions displaying hyperintense core on T2 weighted images (WIs) and hypointense on T1WIs and fluid attenuated inversion recovery (FLAIR) and rim was isointense to hyperintense on FLAIR and hypointense on T2WIs seen in pons (figure 1). MR spectroscopy (MRS) at the site of lesions showed increased lipid peak, decreased $\mathrm{N}$-acetylaspartate peak with increased $\mathrm{Ch} / \mathrm{Cr}$ ratio (figure 2 ). ${ }^{1}$ A tubercular aetiology was further supported by positive cerebrospinal fluid PCR for Mycobacterium tuberculosis. A diagnosis of brain stem tuberculoma was considered. Antituberculous treatment and

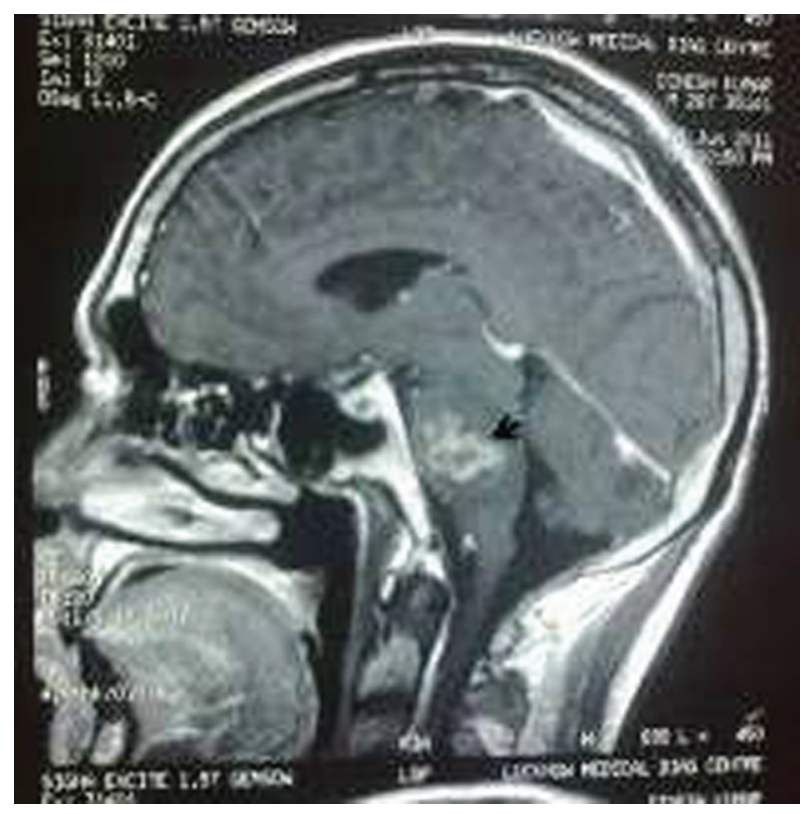

Figure $1 \mathrm{MRI}$ saggital view shows multiple conglomerated ring enhancing lesions (arrow) in pons displaying hypointense core on T1W with perilesional oedema. corticosteroids were started and after 2 weeks, he became able to walk with support (muscle power $4 / 5$ ), hoarseness and dysphagia also decreased. At follow-up after 1 month, he regained complete muscle power, dysphagia resolved but bit hoarseness persisted. He recuperated completely by the end of 3rd month. MRI study has been used in the diagnosis of tuberculoma in the brain, brainstem ${ }^{2}$ and spinal cord, but MRI features of tuberculosis (TB) abscesses are non-specific and may mimic abscesses of other infectious aetiology. MRS may increase specificity of diagnosis by identifying lipids within the lesions that are considered characteristic for TB. Invivo and invitro MRS has shown elevated lipid peaks within the TB lesions. ${ }^{3}$ Gliomas, metastases, abscesses and demyelinating disease were the differential diagnosis that was considered in our patient. Considering MRS to differentiate the above lesions can be helpful but clearly impracticable in all circumstances even at tertiary centres. Here MRS study safely avoided the need of brain biopsy to confirm the nature of lesion.

\section{Learning points}

- MRS may prove a useful non-invasive investigational tool to differentiate the lesions which are often confused with the inflammatory granulomas.

- The isolated occurrence of pontine tuberculoma is rarely seen. It should be kept as differential diagnosis when patients present with brainstem syndromes, particularly in the areas where tuberculosis is prevalent.

\section{Competing interests None.}

Patient consent Obtained.

\section{REFERENCES}

1. Pretell EJ, Martinot C, Garcia HH, et al. Differential diagnosis between cerebral tuberculosis and neurocysticercosis by magnetic resonance spectroscopy. J Comput Assist Tomogr 2005;29:112-4.

2. Venger BH, Dion FM, Rouah E, et al. MR imaging of pontine tuberculoma. AJNR Am J Neuroradiol 1987:8:1149-50.

3. Santy K, Nan P, Chantana Y, et al. The diagnosis of brain tuberculoma by (1) H-magnetic resonance spectroscopy. Eur J Pediatr 2011;170:379-87. 


\section{BMJ Case Reports}
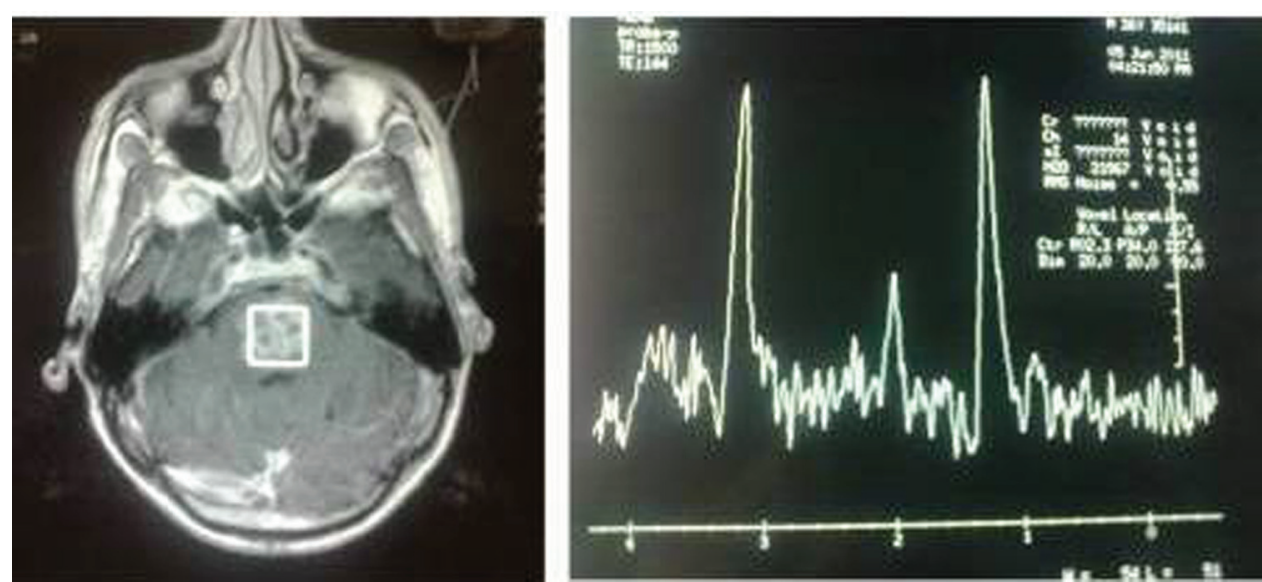

Figure 2 MR spectroscopy at the site of lesion shows increased lipid peak and decreased $\mathrm{N}$-acetylaspartate peak with increased $\mathrm{Ch} / \mathrm{Cr}$ ratio.

This pdf has been created automatically from the final edited text and images.

Copyright 2012 BMJ Publishing Group. All rights reserved. For permission to reuse any of this content visit http://group.bmj.com/group/rights-licensing/permissions.

BMJ Case Report Fellows may re-use this article for personal use and teaching without any further permission.

Please cite this article as follows (you will need to access the article online to obtain the date of publication).

Gutch M, Jain N, Agrawal A, Modi A. MR spectroscopy in tuberculoma of brain. BMJ Case Reports 2012;10.1136/bcr.08.2011.4712, Published XXX

Become a Fellow of BMJ Case Reports today and you can:

- Submit as many cases as you like

- Enjoy fast sympathetic peer review and rapid publication of accepted articles

- Access all the published articles

- Re-use any of the published material for personal use and teaching without further permission

For information on Institutional Fellowships contact consortiasales@bmjgroup.com

Visit casereports.bmj.com for more articles like this and to become a Fellow

Keep up to date with all published cases by signing up for an alert (all we need is your email address) http://casereports.bmj.com/cgi/alerts/etoc 